\title{
o PLANEJAMENTO DO FUTURO
}

\author{
Goffredo da Silva Telles Júnior \\ Professor Catedrático aposentado da Faculdade de \\ Direito da Universidade de São Paulo
}

Resumo:

Governo à deriva! Condição para o desenvolvimento de um país: o plancjamento do futuro. Impossivel confiar esse planejamento ao Poder Legislativo c ao Poder Executivo. Necessidade de um Órgão Planejador, independente dos Poderes c dos partidos políticos: o Conselho Nacional do Planejamento. Conselheiros em número reduzido (vinte ou trinta) designados por um "senso alto" nacional, definido na Constituição.

\begin{abstract}
:
Government at a loss! Condition for a country development : the planning of the future. It is impossible to entrust the Legislative Power and the Executive Power with the task of planning. A Planning Organ working independently from public Powers and from political parties is a necessity: the National planning Council. A short list of members (twenty or thirty people) to be appointed according to a nationwide evaluation of high standard of excellence.
\end{abstract}

Unitermos: desenvolvimento; Conselho Nacional do Planejamento.

Governo à deriva! - Esta é a dura realidade. No Congresso Nacional, total descaso pelos deveres da representação política: inoperância, desmotivação, desfibramento, destempero, subserviência. No Executivo, desdém pela Constituição, descaso pela disciplina jurídica; usurpação de poderes, displicência com o que é essencial para o povo, sujeição a impérios financeiros intervencionistas, enganação.

Entranhado nos tecidos da República, instalou-se o vírus da corrupção, da improbidade, da insensibilidade moral. Por toda parte, um clima de perdição. Uma degringolada da vontade política. 
Mas, no coração dos inconformados, há uma incontida indignação, uma revolta incontrolável - uma onda decidida de oposição e de amor pelo Brasil.

Na verdade, tudo aquilo é uma coisa só: atraso. É atraso de formação, atraso cultural, atraso de senso ético, atraso na definição dos rumos.

Pois bem, o que os inconformados anseiam é sair do atraso. O que querem é o oposto do atraso: é o desenvolvimento de sua Terra.

Enlevados por esta aspiração, eles imediatamente relembram uma lição do passado: a condição preliminar do desenvolvimento é o planejamento do futuro. Este é um valiosíssimo ensinamento, de que se deveria valer o Governo brasileiro.

O que uma velha experiência demonstra é que, nos países do Segundo Mundo - com povos ainda judiados por seu atraso, mas desejosos de progredir - não bastam, para alçá-los na comunidade das Nações, as soluções emergenciais dos problemas de cada hora e de cada lugar. Não bastam as medidas casuisticas, as providências eventuais e contigentes. Em tais países, há necessidade, antes de mais nada, de uma decisiva definição de metas, de uma preordenação de objetivos, de um planejamento transcendente, que inclua, mas ultrapasse, as urgências do hoje, em razão de uma poderosa imagem do futuro.

O que esses países precisam, antes de mais nada, é de uma previsão do porvir, para disciplinar o presente.

Observe-se com atenção: o desenvolvimento verdadeiro não significa apenas crescimento. Ele é crescimento, sem dúvida, mas crescimento aliado ao processo de transformação das estruturas e da melhoria das condições de vida de toda a população.

Tal melhoria não se restringe à costumeira política de amparo a populações carentes. Não se limita à imprescindível política de assistência e de subsídio a este ou aquele setor ou atividade. Nem sequer se reduz à política apressada de obras públicas, de grande ou pequeno porte, sejam de emergência ou sejam de utilidade. E, certamente, não se adstringe à hermética e acaparadora política da alta finança internacional.

Todas essas políticas, e tantas outras, mesmo as que precisam ser realizadas já, inadiavelmente, deverão ser harmonizadas com os imperativos de uma programação global, de um projeto nacional supremo, para que todas as vantagens e lucros se articulem com o aperfeiçoamento geral das condições de vida da população tomada como um todo.

Tal é o motivo pelo qual a política do verdadeiro desenvolvimento de uma Nação não somente se aterá aos dados da estação presente, mas, sobretudo, se há 
de iluminar com a visão telescópica das estações do futuro. Em verdade, ela forçosamente exprimirá uma sábia preconização, relativa aos diversos setores fundamentais da vida do povo e do Estado.

Importante, pois, extraordinariamente importante, é a eminente obrigação do Governo de fazer o seu planejamento do futuro.

Mas cumpre assinalar que não deve a Constituição confiar tal encargo ao presidente da República, nem a ministros. Não deve confiá-lo à Câmara dos Deputados, nem ao Senado.

Planejar o futuro do País é obra política, sem dúvida, mas não pode ser misturado e confundido com apaixonadas preocupações menores, tão freqüentes nas políticas domésticas do Congresso Nacional e dos partidos; nem pode ser obumbrada pelos projetos temporários de flutuantes Ministérios. É obra excelsa, necessariamente infensa ao contágio das ambições de cargos e de Poderes, e incontaminável por seduções e vanglórias da Presidência da República.

Para o presidente, e para os senadores e deputados, as premências assoberbantes do presente e as aspirações naturais das campanhas em curso constituem um biombo: biombo inevitável, mas opaco, obscurecendo e ocultando as exigências do futuro.

Já se tem dito e repetido que o futuro não se comprime em esquemas de curto prazo. De fato, planejar o futuro é façanha que não se prende a legislaturas, e não se submete às imposições do orçamento anual. É obra que não se vincula a circunstâncias do momento, nem às crises de um período.

Tal planejamento é operação que tem começo, mas que jamais termina, porque se vai processando, ininterruptamente, no mesmo passo em que suas metas evoluem e se atualizam, cintilantes como estrelas condutoras, no firmamento da política nacional.

Em conclusão: para planejar o futuro, um novo órgão se impõe: o Órgão Planejador. O professor Fábio Konder Comparato foi quem primeiro o recomendou. ("Muda Brasil" ed. Brasiliense, pp. 24 e 25; "Documentos brasileiros" n. 196, ed. José Olímpio, seção IV). Eu, também, a ele me tenho referido reiteradamente, mas lhe dando estrutura diversa. Nós o denominamos Conselho Nacional do Planejamento.

Esse novo órgão, com quinze ou vinte titulares, talvez trinta, não mais, poderia ser criado pela Constituição, nos seguintes termos : “Art. 2. São Poderes do Governo, independentes uns dos outros, harmônicos entre si, o Legislativo, o Executivo e o Judiciário, assessorados pelo Conselho Nacional do Planejamento" 
O domínio de competência do Conselho não se confundiria com os da Câmara dos Deputados e do Senado, embora as funções das três Casas fossem reciprocamente complementares.

Ao Conselho Nacional do Planejamento não seria dada a competência de legislar. O que lhe caberia seria o planejar.

No exercício autônomo de seu específico labor, na faina de realizar plenamente a sua multifária e envolvente obra planejadora, o Conselho haveria de se manter em comunicação permanente com os centros de estudo e pesquisa mais credenciados do País. Haveria de solicitar a colaboração das entidades especializadas e das autoridades de notável saber, assim como dos representantes autorizados das categorias e classes de trabalho, de que é constituído o povo. Haveria de se manter atento aos movimentos sociais significativos, permanecendo sempre sensível aos anseios profundos da multidão; aos ventos e às marés da História.

De imediato, o Conselho seria levado, certamente, a projetar as grandes linhas da necessária reforma partidária. Ele haveria de renegar, sem dúvida, os atuais extravios. Conseqüentemente, não admitiria, no rol dos partidos políticos, agremiação que não estivesse a serviço de ideais de interesse coletivo, claramente enunciados em seu programa de luta. E prognosticaria, por força, os imperativos do regime de fidelidade partidária, a fim de tornar realidade a representação política - ou seja, para suscitar a eclosão, em nossa terra, de uma Democracia de verdade.

Radicalmente incompatível com o retrocesso, o Conselho teria, de pronto, nos dias de hoje, a missão urgente de reproclamar as olvidadas competências e funções do Legislativo, e de denunciar a inconstitucionalidade da usurpação dos Poderes do Congresso Nacional pelo Poder Executivo de um extraviado presidente da República.

Entre as atribuições do Conselho, inscrever-se-ia a de suscitar, perante o Judiciário, a incompatibilidade de leis e atos que contrariassem normas legais ou constitucionais de seus planejamentos, assim como a de apontar omissão no cumprimento do dever, em caso de inexecução do que, em tais normas, esteja prescrito.

Observe-se que o Conselho Nacional do Planejamento seria uma instituição absolutamente apartidária. A designação dos Conselheiros não poderia depender de filiações políticas, mas exclusivamente de seu alto valor próprio e de sula própria reconhecida competência.

Como se faria essa designação?

Tudo parece indicar que ela deveria resultar de uma consulta periódica, talvez decenal, a um "senso alto" nacional, definido na Constituição. 
Dimanado de uma tal sondagem, o Conselho do Planejamento seria uma equipe de "excelência" assessoria preciosa dos Poderes da República, inteiramente dedicada à elaboração e à eficiência do Programa de Metas da Nação.

São Paulo, 12 de março de 2001. 